\title{
Možnosti, perspektívy a úskalia integrácie pedagogiky M. Montessoriovej a digitálnych technológií
}

\author{
Matej Slováček \\ Základná škola Ruskov; \\ Slovenský výbor Svetovej organizácie pre predškolskú výchovu OMEP
}

Marec 2020 (a následne školský rok 2020/2021) priniesol aj do slovenského školstva „nový vietor“. Rozdúchala ho pandémia COVID-19, ktorá zastavila a súčasne pohla lady rutiny takmer v celom svete. Cielom diskusného príspevku bude prezentovat' a hodnotit' možnosti, výhody aj nevýhody integrácie pedagogiky M. Montessoriovej a digitálnych technológii v materskej škole, a tak otvorit’ odbornú diskusiu na danú tému. Text diskusie je štruktúrovaný do štyroch častí. V úvode opisujem chronologický pohlad na zmeny, ktoré predchádzali úpravám a inováciám v školstve na Slovensku, ktoré sú podnietené pandémiou COVID-19. V prvej časti sa venujem stručnej deskripcii pedagogiky M. Montessoriovej u nás aj v Českej republike, ktoré považujeme za dôležité uviest', aby sme čitatel'a diskusie oboznámili so súčasným trendom týkajúcim sa tejto pedagogickej koncepcie a jeho popularizácie, renesancii. V druhej časti opisujem dôvody a odpovedám na otázky Čo? a Ako? ma motivovalo a ovplyvnilo v úvahách o digitálnych technológiách a pedagogike M. Montessoriovej. V tretej časti prezentujem aktivity, ktorými môžeme integrovat' digitálne technológie do procesu výchovy, vzdelávania a výcviku podla M. Montessoriovej, ale aj integrovat' pedagogiku M. Montessoriovej do výchovy, vzdelávania a výcviku využívajúcich digitálne technológie. V poslednej časti sa snažím odpovedat' na otázku aké miesto vo výchove, vzdelávaní a výcviku dnešných detí majú digitálne technológie? Vyslovujem mnou vnímané perspektívy a úskalia.

Začnime však poporiadku a pripomeňme si zmeny slovenského školstva. Slovenská republika a jej školstvo prešlo mohutnou školskou reformou v roku 2008.

Rok 2008 bol pre školstvo na Slovensku vel'mi významným a dôležitým rokom. Začali sa postupne plnit' d'alšie dôležité návrhy vyplývajúce z Milénia (koncepcie výchovy a vzdelávania na 15-20 rokov). Obsahová reforma v podobe aj návrhov zmien v legislatíve dosiahla svoj úspech 22. 5. 2008 kedy bol prijatý nový zákon č. 245/2008 Z. z. o výchove a vzdelávaní (školský zákon). (Miňová, 2009, s. 141) 
Na základe tohto bol reformovaný obsah vzdelávania na všetkých stupňoch škôl. Materské školy boli zaradené do systému škôl (aj ked' nepovinne). Dovtedajší Program výchovy a vzdelávania detí v materských školách (Gruziová et al., 1999) nahradil Štátny vzdelávací program ISCED 0 - predprimárne vzdelávanie (2008), ktorý prichádza s novým formálnym členením obsahu na obsahové a vzdelávacie štandardy $\mathrm{v}$ rámci tematických okruhov a vzdelávacích oblastí.

Vel'kým prínosom pre materské školy boli tri dôležité momenty: (1) vytvorenie metodickej príručky k Tvorbe školského vzdelávacieho programu pre materské školy, (2) vzdelávanie riaditeliek materských škôl ku tvorbe školského vzdelávacieho programu, (3) vzdelávanie učiteliek materských škôl ku tvorbe školského vzdelávacieho programu (Miňová, 2009, s. 141).

Nové štátne vzdelávacie programy dostali aj vyššie stupne školského systému. Ďalšia kurikulárna reforma prišla v roku 2015, nový Štátny vzdelávací program pre predprimárne vzdelávanie v materských školách dostali aj materské školy v roku 2016. V septembri 2019 vstúpil do platnosti nový Zákon 138/2019 o pedagogických zamestnancoch a odborných zamestnancoch, ktorý o. i. zrušil od roku 2009 platný kreditový systém kontinuálneho vzdelávania pedagogických a odborných zamestnancov a priniesol novo definovaný profesijný rozvoj. Napokon sme s platnostou od 16. marca 2019 rozhodnutím ministerky školstva, vedy, výskumu a športu prerušili prezenčnú formu výchovy a vzdelávania $v$ školách (v dôsledku svetovej pandémie) a začali aktívne učit' dištančne. $V$ tom čase sa na Slovensku o. i. aj menila vláda, minister, názory. Dnes, v roku 2020/2021 sa vyučuje zatial' zväčša dištančne (druhý stupeň základných škôl a stredné školy) i prezenčne (materská škola a primárne vzdelávanie)... avšak digitálne technológie, komunikačné aplikácie sa stále viac dostávajú do popredia nielen v procese výchovy, vzdelávania a výcviku detí a žiakov, ale aj v procese profesijného rozvoja (d’alšieho vzdelávania) našich učitelov a iných pedagogických a odborných zamestnancov školstva.

Nielen tieto udalosti okolo pandémie na Slovensku prinášajú do pedagogickej diskusie otázky digitálnych technológií vo vyučovaní detí a žiakov.

\section{Pedagogika M. Montessoriovej na Slovensku (a v ČR)}

Už spomenutá pedagogika M. Montessoriovej je „trendy“ a stále aktuálna a aktuálnejšía na Slovensku, aj ked' má vo svete storočné korene, v Českej republike a na Slovensku ide o alternatívu pomerne novú, nakol'ko jednotný 
školský systém zavedený v týchto krajinách v roku 1948 a trvajúci takmer do konca 20. storočia, neumožnil využívat’ vedla hlavného prúdu iné alternatívy. Nakol'ko sa pedagogika M. Montessoriovej radí v súčasnosti k prúdu alternatívnej pedagogiky, považujem za vhodné stručne uviest' aktuálne podujatia a aktivity, ktoré pozorujeme vo vztahu k trendom v náraste a popularizácii pedagogiky M. Montessoriovej na Slovensku.

V roku 2018 usporiadala Pedagogická fakulta Univerzity Mateja Bela v Banskej Bystrici dvojdňové medzinárodné sympózium venované pedagogike M. Montessoriovej. Na Prešovskej univerzite sa aj v rámci vzdelávania budúcich učitelov konal projekt Návraty Montessori $k$ budúcim učitelom ${ }^{1}$. Projekt č. 2013vv32 bol realizovaný v období od septembra 2013 do júla 2014. Bol podporený Nadáciou Tatra banky prostredníctvom grantovej schémy Vediet' viac 2013. V projekte spolupracovala Pedagogická fakulta Prešovskej univerzity v Prešove s občianskym združením EMERKA - rodinné oddychové centrum, ktoré sídli v Prešove. Cielovou skupinou, na ktorú bol projekt zameraný sú študenti odboru predškolská a elementárna pedagogika a predškolská a elementárna pedagogika psychosociálne narušených, ktorí sa pripravujú na povolanie učitelov v materských školách a vychovávatel'ov v školských zariadeniach (školské kluby detí, centrá vol'ného času, školské internáty). Riešitel'mi projektu boli Mgr. Marta Fudalyová, Mgr. Martina Vinjarová, PaedDr. Erika Novotná, PhD. (Novotná, 2014). Vybraná skupina študentov sa v Montessori centre zriadenom o. z. Emerka priamo zúčastňovala procesu rozvoja osobnosti diet'ata prostredníctvom Montessori pedagogiky v uzavretých skupinách. Tematické zameranie Montessori modulov bolo nasledovné: cvičenia každodenného života, rozvíjania zmyslov, rozvoj geometrickej predstavivosti, praktická matematika, jazyk a reč, zoológia, botanika, kozmická výchova a geografia. Ako sme už spomínali vyššie:

Jedným z prostriedkov dosiahnutia cielov projektu bol aj odborný seminár nazvaný Montessori v priestore formálneho a neformálneho vzdelávania, ktorý sa uskutočnil na PF PU v Prešove v októbri 2013. Odborný seminár bol venovaný filozofii Montessori pedagogiky a jej prínosu pre prax budúcich učitelov (Novotná, 2014, s. 9).

Experimentálne overovanie, týkajúce sa pedagogiky M. Montessoriovej naSlovensku, bolo schválené Ministerstvom školstva, vedy, výskumu a športu Slovenskej republiky 30.05.2011 s účinnost'ou od 01.09.2011 (Rozhodnutie

1 Autor príspevku je absolventom vzdelávania v rámci projektu č. 2013vv32 Návraty Montessori k budúcim učitelom. 
číslo: 2016-8672/15327:4-100B, 2016, zdroj: www.statpedu.sk). Išlo o schválenie experimentálneho overovania výchovno-vzdelávacieho programu pedagogickej koncepcie M. Montessori pre predprimárne vzdelávanie na Súkromnej základnej škole s materskou školou Márie Montessori, Borinská 23, Bratislava. Zo záverov hodnotiacej správy vyplynulo, že výskum v oblasti výchovno-vzdelávacích výsledkov potvrdil vel'mi dobrú úroveň vo všetkých sledovaných oblastiach rozvoja detí. Na základe vyššie uvedeného boli schválené výsledky experimentálneho overovania, ktoré sa týkajú školského vzdelávacieho programu Súkromnej základnej školy s materskou školou, Borinská 23, Bratislava, a „uplatňovania pedagogickej koncepcie Marie Montessori a jej prvkov vo výchovno-vzdelávacom procese $\mathrm{v}$ predprimárnom vzdelávaní v materských školách, zaradených v sieti škôl a školských zariadení Slovenskej republiky“.

V poslednej dobe bolo na Slovensku publikovaných aj niekol'ko odborných textov o tejto pedagogike, čo podporuje moje tvrdenie o raste „popularity“ pedagogiky M. Montessoriovej: Spolok Slovákov v Pol'sku a Trnavská univerzita, Filozofická fakulta vydali prácu Poruchy vyšších zrakových funkcií detí $s$ detskou mozgovou obrnou: Montessori terapia (Kozelková, 2013). V tom istom roku Metodicko-pedagogické centrum v Bratislave zasa Pomôž mi, aby som to urobil sám: Úvod do pedagogiky M. Montessori (Kosová, Almáši Koreňová, \& Cinová, 2013). Pedagogická fakulta Masarykovej univerzity v súčasnosti realizuje projekt MUNI/FR/0997/2019 Tvorba metodik pro práci s vybranými Montessori pomůckami pro matematiku jako opora pro vzělávání budoucích učitelů různých oborů. Obdobie riešenia je nastavené na 1/2020-12/2020, ciel'om projektu je vytvorit' súbor vybraných pomôcok (montessori materiálu) a ich metodík, kvôli aktuálnej potrebe zaradit' prácu s montessori matematickým materiálom do prípravy budúcich učitel'ov pre odbory: Špeciálna pedagogika, Učitel'stvo matematiky pre základné školy, Učitel'stvo pre 1. stupeň základnej školy. Dôvodom je, podla opisu projektu, vysoká využitel'nost' týchto materiálov vo vyučovaní matematiky (Mgr. Lenka Pavlíčková, Ph.D., Mgr. Eva Nováková, Ph.D.). Katedra primárnej pedagogiky Pedagogickej fakulty Masarykovej univerzity v Brne pod vedením Mgr. Petry Vystrčilovej, Ph.D. realizovala výskumný projekt MUNI/FR/0902/2017 Individualizace $v$ primárním vzdělávání - přirozené učení s respektujícim př́istupem podle Montessori pedagogiky. Trvanie tohto projektu bolo v období od 1/2018 do 12/2018 (www.muni.cz). 
Rastie aj záujem o vzdelávanie, či už zo strany učitel’ov alebo rodičov. $\mathrm{Na}$ Slovensku ho poskytujú MVDr. Eva Štarková, Slovenská asociácia Montessori, prebieha prvý diplomovaný kurz Montessori pedagóg ZŠ pozostávajúci z troch samostatných ročných úrovní, a je venovaný učitelom základných škôl pre prácu s det'mi na základných školách, organizátor Občianske združenie Monte plus, Bratislava (www.monteplus.sk). Na Slovensku taktiež Uni Kredit nezisková organizácia ponúkala kontinuálne vzdelávanie pedagogických zamestnancov materských škôl v zmysle zákona platného do 31.8.2019 s názvom Aplikácia prvkov alternatívnej pedagogickej koncepcie M. Montessori v predprimárnej edukácii (15 kreditov). Pedagogický zamestnanec po skončení programu zdokonalí a rozšíri svoje kompetencie v oblasti implementácie prvkov alternatívnej koncepcie M. Montessoriovej do svojej každodennej pedagogickej praxe (www.unikreditbb.sk). V Českej republike je ich viac ako na Slovensku, spomeňme Ročný diplomovaný kurz Akademie Montessori Biberkor, ktorý je integrovaným celostným programom, ktorý kombinuje tradičné základné AMI kurzy (3-6, 6-12, 12-16 rokov) a zároveň pripravuje na efektívnu integráciu detí so špeciálnymi výchovno-vzdelávacími potrebami (www.erudio-montessori.cz), diplomované vzdelávanie Společnosti Montessori (www.montessoricr.cz), alebo AMI Prague (www.amiprague.cz). Rovnako je v Českej republike dostupná aj ponuka webinárov zväčša orientovaných na výchovu detí v domácom prostredí, ktoré sú pripravené primárne pre rodičov. Aj tieto skutočnosti v integrácii s aktuálnym stavom spoločnosti ma podnietili k úvahám. Efektivitu, účelnost' a aktuálnost' pedagogiky M. Montessoriovej nemožno spochybňovat'. Aké sú ukazovatele jej aktuálnosti? Je možné pedagogiku M. Montessoriovej implementovat' aj do vyučovania digitálnymi technológiami?

\section{Pedagogika M. Montessoriovej - digitálne}

Predprimárne obdobie vzdelávania je jedno z najsenzitívnejších a najhektickejších období v živote každého človeka. V tomto období, pri kvalitnom a efektívnom vedení, môžeme diet’a doviest' $\mathrm{k}$ tomu, že úspešne bude zvládat' podmienky základnej školy, najprv prvého stupňa (Miňová, 2010). Preto musíme uvažovat' nad otázkou Ako?, aj vo vzt’ahu k digitálnym kompetenciám, ktoré môžeme v kontexte pedagogiky M. Montessoriovej priradit’ do oblasti Cvičenia každodenného života.

Obdobie pandémie a dištančného vyučovania aj vzdelávania sa pedagogických zamestnancov prinieslo na trh ponuku mnohých webinárov, ktorými si učitelia aj na Slovensku rozvíjali vlastné odborné kompetencie 
a zabezpečovali vlastný profesijný rozvoj, ma priviedlo k absolvovaniu o. i. aj on-line vzdelávania Projektové vyučovanie, či programov o vyučovaní na dial'ku. Začal som uvažovat' nad pedagogikou M. Montessoriovej aj v iných súvislostiach. „Hlavným ciel'om montessoriovského vzdelávania je pripravit' deti pre život ulahčením ich normalizačného procesu k dosiahnutiu maximálne možného rozvoja osobnosti“ (Rýdl, 2007, s. 35). Obsah výchovy, vzdelávania a výcviku v tejto pedagogike je členený do oblastí Cvičenia každodenného životy, Zmyslová výchova, Matematika, Jazyk a Kozmická výchova. V kontexte využívania digitálnych technológií ma zaujali Cvičenia každodenného života. Novotná (2017) uvádza, že členovia generácie Z sú stotožnení s technológiami a sú v interakcii s internetom, sociálnymi sietami, ktoré pre nich predstavujú významný podiel ich spoločenského života. Deti generácie $Z$, narodené po roku 2000 sa v technike vyznajú. My, ich učitelia, vychovávatelia (aj rodičia), musíme k týmto detom pristupovat' v zmysle týchto možno povedat' „vrodených“ špecifík. Musíme sa skrátka prispôsobit’. Podla Zelinkovej (1997) Cvičenia každodenného života sú aktivity tvoriace jednu z nosných oblastí pedagogiky M. Montessoriovej. Obsah týchto cvičení Montessoriová rozdelila do troch podskupín: Cvičenia sebaobsluhy (hygiena, obliekanie a vyzliekanie, stravovanie a stolovanie, chôdza...); Cvičenia zamerané na kontakt s l'ud'mi (pozdrav, d'akovanie, rozprávanie sa...); Cvičenia zamerané na starostlivost' o okolie (starostlivost' o rastliny a živočíchy, prenášanie, prelievanie, presýpanie, čistenie, zametanie...). Prácu s počítačom, tabletom, digitálnou čítačkou kníh môžeme zaradit' do Cvičení zameraných na kontakt s l'ud'mi. Ide o prístroje a technológie, ktoré nám umožňujú komunikovat', či už cez sociálne siete, alebo komunikovat' informácie na ceste dnu a von. Deti by sme mali učit’ ako tieto technológie účelne a funkčne a v neposlednom rade bezpečne využívat'. Ideálne prostredníctvom hry. Miňová, Muchacki a Portik (2016, s. 228) definujú hru z pohladu tradičnej pedagogiky nasledovne „hra - špecifická forma činnosti vykonávaná človekom od raného detstva až po starobu, ktorá sa líši od práce a učenia, je najprirodzenejšou činnost'ou v predškolskom veku, forma vzdelávania, modelový scenár pre diet’a“. V kontexte nami analyzovanej pedagogiky preferujeme a používame pojem práca.

Otáznym je spojenie digitálnych technológií a montessori materiálu. Ako pracovat's digitálnymi technológiami? Ako ich integrovat's montessori materiálom? Je to $v$ zmysle princípov tejto pedagogiky možné? Rešpektuje to jednu z myšlienok Ruka je nástrojom ducha? Vieme, že za základ pedagogiky M. Montessoriovej môžeme považovat' skúsenostné, zmyslové učenie 
priamym zážitkom, prostredníctvom práce s didaktickým materiálom v pripravenom prostredí v rámci senzitívnych fáz diet’ata. Využívanie digitálnych technológií (čo najmenej, čo najefektívnejšie) považujme za nevyhnutnost' v kontexte dneška a špecifík generácie dnešných detí. Uvažovali sme a analyzovali vybraný didaktický materiál, v tomto príspevku uvádzame ukážku možností využitia dvoch materiálov. Prvého z oblasti Zmyslová výchova a druhého $\mathrm{z}$ oblasti Matematika. Oba však využívame na rozvíjanie matematických kompetencií detí. Aktivity sme nastavili pre možnost' využívania interaktívnej tabule alebo tabletu. Opisujeme využitie aplikácie kahoot.it a snažíme sa využit' didaktický materiál na plnenie minimálne jedného ciela jeho využitia. Aplikácia funguje na báze výberu z odpovedí, resp. možností.

V nasledujúcej časti budeme uvádzat' aktivity s využitím dvoch materiálov typických pre Montessori aktivity - ružová veža a červeno-modré tyče. Cielom práce s ružovou vežou je rozvíjat' jemnú motoriku, spresňovat' koordináciu pohybov, utvárat' zmysel pre usporiadané štruktúry, oboznamovat's pojmami vel'ký, malý, väčší, menší, najväčší, najmenší. Cielom práce s červeno-modrými tyčami je o. i. naučit' sa počítat' od jeden do desat', poznat' postupnost' čísel (aj vel'kostí).

\section{Aktivity: montessori a digitálne technológie - možnosti}

Možností integrácie na pohl'ad neintegrovatel'ného môže byt' niekol'ko. V auguste 2020 som bol aktívne účastný na online Community Conversations: The Shape of What Comes Next, kde boli hlavnými rečníkmi Dr. Marc T. Frankel a Judith Schechtman, M.S.W. Diskutovalo vyše 120 zainteresovaných z mnohých krajín sveta (USA, Kanada, aj štáty Európy a Ázie...). Organizátormi boli Lead Montessori \& Asociace Montessori Česká republika. Aj toto stretnutie potvrdilo moje myšlienky a názory, že predmetná pedagogika sa stále rozvíja, resp. prispôsobuje dobe (aj vo využívaní digitálnych technológii, dial'kového vzdelávania výchovy a výcviku, ale nielen $\mathrm{v}$ nich). Je podnetné si vždy položit' otázku: Čo by (u)robila Mária Montessoriová? Vhodné je mysliet' na to, že jej cielom bolo stručne povedané vychovat' samostatného, sebavedomého, slobodného, zodpovedného a dobrého človeka.

Prvou z možností, ktorá bola a je reálne využívaná v zahraničí, kde pedagogika M. Montessoriovej a jej škole nie je „iba“ alternatívou, je (a v čase pandémie a dištančného vzdelávania aj musí byt') vyučovanie on-line. 
Kolegyne a kolegovia z vyššie spomenutej medzinárodnej komunikácie uviedli, že vyučujú cez platformu Zoom. Vyučovanie je realizovatel'nejšie na základnej, či strednej škole, ale aj v materskej. Cez Zoom je možné o. i. detom a žiakom rozprávat' príbehy, napríklad o vzniku písma, o vzniku sveta a rozprávat' sa s nimi o tom. Druhou možnost'ou, ktorú sme rozpracovali do prostredia materskej školy v kontexte na Slovensku platného kurikula predprimárneho vzdelávania, je využívanie digitálnych technológii počas prezenčnej formy výchovy, vzdelávania a výcviku (za istých podmienok - pomoc rodiča, je to možné aj počas dištančnej formy). Možnostou je učit' deti pracovat' s tabletom alebo interaktívnou tabulou. S prihliadnutím na materiálno-technické podmienky a vybavenie takmer všetkých materských škôl na Slovensku ide skôr o využívanie interaktívnej tabule. Využitel'ná je aplikácia kahoot.it. Aktivity s touto aplikáciu opisujeme nižšie.

\section{Aktivita s obdobou ružovej veže}

Vzdelávacia oblast: Matematika a práca s informáciami; Podoblast': Logika; Výkonový štandard: Vytvorí dvojicu objektov na základe danej logickej súvislosti. Výchovno-vzdelávací ciel: Priradit' kocku k podstave podla vel'kosti pomocou aplikácie kahoot.it. Metodický postup a opis: Na interaktívnej tabuli zapnem aplikáciu (hru) kahoot.it. Úlohou detí bude určit', zvolit', ktorý štvorec (podstava) patrí ku ktorej ružovej kocke podl'a vel'kosti. Deti musia priradit' podstavu ku kocke na základe vel'kosti. Aktivitu majú zažitú s reálnou ružovou vežou. U detí rozvíjam matematické predstavy (vel'kost', geometrické útvary a telesá) (obrázok 1 a 2). Obrázok 1 a 2 prezentujú ukážku úlohy v aplikácii kahoot.it, ktorú vidia deti. Možností sú rozdelené farebne a označením útvarom. Dieta dotykom, označí odpoved', ktorú považuje za správnu. Kahoot.it odpovede vyhodnotí.

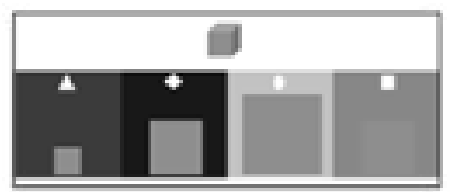

Obrázok 1. Aktivita s ružovou kockou 1. Vlastné spracovanie. 


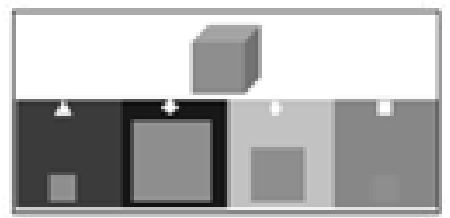

Obrázok 2. Aktivita s ružovou kockou 2. Vlastné spracovanie.

Aktivita s obdobou červeno-modrých tyčí

Vzdelávacia oblast: Matematika a práca s informáciami; Podoblast: Čísla a vztahy; Výkonový štandard: V obore do 10 určí počítaním po jednej počet predmetov v skupine. Výchovno-vzdelávací ciel: Priradit' číslo (počet) k tyči podla počtu jej dielikov pomocou aplikácie kahoot.it. Metodický postup a opis: Na interaktívnej tabuli zapnem aplikáciu (hru) kahoot.it. Úlohou detí bude určit', zvolit', ktoré číslo patrí danej červeno-modrej tyči. Deti musia spočítat' dieliky na tyči a určit' ich počet (Obrázok 3). Obrázok 3 obsahuje ukážku úlohy s červeno-modrou tyčou. Možností sú rozdelené farebne. Dietáa dotykom, označí odpoved', ktorú považuje za správnu. Podobná aktivita sa robí aj s originálnym hmotným priestorovým materiálom. Kedy sa pracuje $\mathrm{s}$ červeno-modrými tyčami a šmirglovými číslami.

Deti môžu pracovat' individuálne aj vo dvojiciach. Pri práci vo dvojiciach sa snažím, aby sa deti striedali, ak jeden nevie, prenechá „t'ah“ druhému. Dbám na slušnú a zdvorilú komunikáciu medzi det'mi.

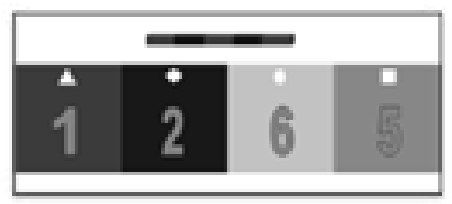

Obrázok 3. Aktivita s červeno-modrou tyčou. Vlastné spracovanie.

Využívanie spojenia pedagogiky M. Montessoriovej a digitálnych technológií v edukačnej praxi materskej školy je možné (a vhodné) zaradit' účelne, nie náhodne. Môže íst' na jednej strane o možnost' výberu pre diet’a (spravidla v originálnom montessori prostredí - v rámci súčasného právneho stavu 
nie je možné, ak považujeme za materskú školu inštitúciu zaradenú v sieti škôl a školských zariadení Ministerstva školstva, vedy, výskumu a športu Slovenskej republiky), na druhej strane o využívanie v kurikulárnom projekte v materskej škole, ktorá má, alebo nemá prvky pedagogiky M. Montessoriovej implementované vo svojom školskom vzdelávacom programe. „Kurikulárne projektovanie v materskej škole je zaujímavou možnostou ako spracovat', analyzovat' a det'om sprostredkovat' obsah vzdelávania a výchovy, smerovat' k dosahovaniu kompetencií v zmysle vzdelávacieho programu" (Slováčková, 2019/2020, s. 43).

\section{Ruka je nástrojom ducha, alebo aké miesto vo výchove, vzdelávaní a výcviku dnešných detí majú digitálne technológie? - perspektívy a úskalia}

V praxi pedagogiky M. Montessoriovej je dôležité a neopomenutel'né (1) zmyslové učenie sa, (2) učenie sa zážitkom, (3) učenie sa bezprostrednou skúsenostou. Práca s rukou, respektíve manipulácia s didaktickým materiálom je základnou doménou tohto procesu.

Ako som spomenul vyššie, dnešné deti sa rodia „, mobilom v ruke“. Je preto nereálne, aby sme aj v kontexte praxe alternatívnych, reformno-pedagogických, či inovatívnych koncepcií digitálne technológie, pomôcky a materiál (hračky) tabuizovali. Práve naopak, naším poslaním ako učitelov (aj rodičov) je facilitovat' pri vžívaní sa diet'ata do kultúry, zvykov a každodenného života. Preto sme prácu s digitálnymi technológiami zaradili do oblasti Cvičenia každodenného života.

Predmetná diskusia a vyššie prezentované možnosti môžu byt' chápané $\mathrm{v}$ dvoch smeroch. Prvým je smer integrovania prvkov pedagogiky M. Montessoriovej do tradičnej materskej školy s využitím digitálnych technológií. $\mathrm{V}$ tomto prípade je takáto práca podobná s inými aplikáciami, ktoré sú dostupné, avšak materiál montessori má prvky medzinárodnosti (ružová veža je rovnaká v každej krajine, v každej montessori škole), je možnost' poznania det'mi, ak majú montessori materiál doma a podobne. Druhým smerom je integrovanie digitálnych technológií do pedagogiky M. Montessoriovej, ktorým aj táto škola „pôjde s dobou“. Deti sa naučia pracovat' s digitálnymi technológiami, zároveň pracujú so známym materiálom. Cítia sa bezpečne. Možností pre prácu je mnoho: individuálna práca, práca vo dvojiciach, skupinová práca a podobne. Tu zohráva rolu erudovanost' učitel'ky/učitel'a a jeho pedagogické majstrovstvo. 
To je perspektíva (+) a súčasne prevencia proti negatívnym, často až patologickým javom, ktoré u detí vo vzt'ahu k digitálnym technológiám vznikajú (závislost', agresivita...). Ked' budeme deti od raného a predškolského veku učit’ načo a ako nám slúžia, resp. pomáhajú digitálne technológie a naučíme ich s nimi racionálne a funkčne pracovat' (samozrejme s mierou!), vtedy budú naše deti samostatné a zodpovedné v práci a manipulácii s nimi.

Úskalím (-) najmä v tradičnej materskej škole, môže byt' postupné nadmierne využívanie týchto moderných vymožeností, a to v dôsledku „pohodlnosti“ učitel'ky a učitela $v$ príprave na výchovno-vzdelávací a výcvikový proces. Úskalím v praxi pedagogiky M. Montessoriovej (a nielen v nej) je nedostatočnost' zjemňovania a rozvíjania zmyslov, najmä hmatu, kedy prsty (často iba jeden - ukazovák) na hladkej obrazovke, ktorá nevyžaduje námahu, tlak ruky a často ani presnost', nedostávajú dostatok podnetov. Preto je vhodné prácu s digitálnymi technológiami plánovat’ v maximálne minimálnej miere a kompenzovat' (viac ako bežne) prácou s hmatovými doskami, formami povrchu, šmirgl'ovými číslicami, či písmenami. Pretože sa nesmie stat', že základy výchovy, vzdelávania a výcviku v pedagogike M. Montessoriovej sa vytratia na úkor hocičoho, nielen digitálnych technológií. Pretože: „Práca so zmyslovým materiálom výrazne podporuje intelektuálny vývin diet’ata: vnímanie, triedenia, zapamätávanie, vybavenie z pamäti a pozorovanie sú psychické procesy ... Zmyslová výchova tvorí základ, z ktorého sa dalej rozvíja jazykové vyjadrovanie a matematické myslenie“ (Anderlik, 2019, s. 32).

\section{Slovo na záver}

Cielom príspevku bolo prezentovat' a hodnotit' možnosti, výhody aj nevýhody integrácie tejto pedagogiky a digitálnych technológii v materskej škole, a tak otvorit' odbornú diskusiu na danú tému. Uviedli sme dve možnosti: (1) Zoom on-line vzdelávanie, (2) kahoot.it aplikáciu. Možnosti integrácie témotvorných konceptov nášho príspevku sme zhodnotili vo vztahu k jej perspektívam aj úskaliam. Digitálne technológie sa stali súčastou každodenného života nás aj našich detí, i žiakov. Musíme dietáa vnímat' ako celok a aj preto potrebujeme v kontextoch dnešnej doby implementovat' do edukačného procesu aj prácu s digitálnymi technológiami, aby sme deti naučili ich efektívne, účelne a najmä bezpečne využívat'. Nesmieme prácu s nimi tabuizovat', avšak ani preháňat'. Pokúsil som sa načrtnút' možnosti prepojenia pedagogiky M. Montessoriovej a digitálnych technológií so stručným hodnotením. 
Týmto príspevkom rád otvorím širšiu diskusiu a úvahy o týchto témach, ktoré sú nielen perspektívami ale aj úskaliami, a to nielen v pedagogike M. Montessoriovej.

\section{Literatúra}

Anderlik, L. (2019). Jedna cesta pro všechny! Život s Montessori. Praha: Montessori ČR.

Guziová, K., Uherčíková, V., \& Haverlík, I. K. (1999). Program výchovy a vzdelávania detí $v$ materských školách. Bratislava: Ministerstvo školstva SR, Štátny pedagogický ústav.

Kosová, I., Almáši Koreňová, Z. \& Cinová, E. (2013). Pomôž mi, aby som to urobil sám: Úvod do pedagogiky M. Montessori. Bratislava: Metodicko-pedagogické centrum.

Kozelková, M. (2013). Poruchy vyšších zrakových funkcií detí s detskou mozgovou obrnou. Montessori terapia. Trnava/Krakow: Filozofická fakulta TU v Trnave/Towarzysteo Slowaków w Polsce.

Miňová, M. (2009). Zmeny v našom školstve - poznatky a skúsenosti. In M. Podhájecká \& M. Miňová (Eds.), Predprimárna edukácia v podmienkach súčasnej reformy (s. 141-145). Prešov: PU v Prešove, Pedagogická fakulta, SV OMEP.

Miňová, M. (2010). Elementárna gramotnost' v podmienkach materskej školy. In L'. Belásová (Ed.), Aktuálne možnosti utvárania elementárnej gramotnosti (s. 108-115). Prešov: Prešovská univerzita v Prešove, Pedagogická fakulta.

Miňová, M., Muchacki, M. \& Portik, M. (2016). Roma child in the information society. Kraków: Petrus.

Novotná, E. (2014). Návrat montessori k budúcim učitelom. ciele, zámery, torzo projektu. In E. Novotná (Ed.), Montessori v priestore formálneho a neformálneho vzdelávania učitelov (s. 7-10). Prešov: Prešovská univerzita v Prešove.

Novotná, E. (2017). Pedagogika volného času. Teória výchovy mimo vyučovania a vo vol'nom čase. Prešov: Rokus.

Rýdl, K. (2007). Metoda Montessori pro naše dítě: Inspirace pro rodiče a další zájemce. Pardubice: FF Univerzity Pardubice.

Slováčková, D. (2019/2020). Rozprávkový poklad - kurikulárny projekt v materskej škole. Naša škola, 23(5), 38-43.

Štátny vzdelávací program ISCED 0 - predprimárne vzdelávanie. (2008). Bratislava: Štátny pedagogický ústav.

Štátny vzdelávací program pre predprimárne vzdelávanie $v$ materských školách. (2016). Bratislava: Dr. Jozef Raabe Slovensko.

Zákon č. 138/2019 Z. z. o pedagogických zamestnancoch a odborných zamestnancoch a o zmene a doplnení niektorých zákonov.

Zelinková, O. (1997). Pomoz mi, abych to dokázal. Praha: Portál.

\section{Autor}

PhDr.PaedDr. Matej Slováček, Základná škola Ruskov, Ruskov 32, e-mail: slovacekmatej@gmail.com 